\title{
Particle Bombardment Mediated Transformation
}

J.J. Finer ${ }^{1}$, K.R. Finer ${ }^{2}$, and T. PonapPa'

1 Introduction . . . . . . . . . . . . . . . . . . . . . . . . . . . . . . . . . 60

2 History . . . . . . . . . . . . . . . . . . . . . . . . . . . . . . . . . . . 60

3 Particle Gun Design . . . . . . . . . . . . . . . . . . . . . . . . . . . . . 61

3.1 The Original Particle Gun . . . . . . . . . . . . . . . . . . . . . . . . . . . 62

3.2 Helium-Modified Bombardment Device . . . . . . . . . . . . . . . . . . . . 62

3.3 Accel Particle Gun . . . . . . . . . . . . . . . . . . . . . . . . . . . . . . 63

3.4 Particle Inflow Gun . . . . . . . . . . . . . . . . . . . . . . . . . . . . 63

3.5 Microtargeting Device . . . . . . . . . . . . . . . . . . . . . . . 63

3.6 Helios Gene Gun . . . . . . . . . . . . . . . . . . . . . . . . . . . . . . . 64

4 Comparison to Agrohacterium-Mediated Transformation . . . . . . . . . . . . . . . . 64

5 Factors Affecting Particle Bombardment-Mediated Transformation . . . . . . . . . . 65

5.1 Components of the Introduced Plasmid DNA . . . . . . . . . . . . . . . . . . . 65

5.1.1 Selectable Marker Genes . . . . . . . . . . . . . . . . . . . . . . . . . . . 65

5.1 .2 Reporter Genes . . . . . . . . . . . . . . . . . . . . . . . . . . . . . . . . 66

5.1 .3 Introns . . . . . . . . . . . . . . . . . . . . . . . . . . . . . 68

5.1 .4 Promoter Analysis. . . . . . . . . . . . . . . . . . . . . . . . . . . . . . 68

5.1 .5 Codon Usage. . . . . . . . . . . . . . . . . . . . . . . . . . . . . . . . . . . 69

5.2 Target Tissue . . . . . . . . . . . . . . . . . . . . . . . . . . . . . . . 69

5.2.1 Embryogenic Cultures . . . . . . . . . . . . . . . . . . . . . . . . . . . . 69

5.2 .2 Shoot Apical Meristems . . . . . . . . . . . . . . . . . . . . . . . . . . . . 70

5.2.3 Other Target Tissues. . . . . . . . . . . . . . . . . . . . . . . . . . . . . . 71

5.3 Tissue Treatment . . . . . . . . . . . . . . . . . . . . . . . . . . . . . . 71

6 The Fate of the Introduced DNA(s) . . . . . . . . . . . . . . . . . . . . . . . . . . . . . 72

6.1 Recombination . . . . . . . . . . . . . . . . . . . . . . . . . . . . . 72

6.1 .1 Position Effect . . . . . . . . . . . . . . . . . . . . . . . . . . . . . . . . 73

6.1 .2 Co-suppression . . . . . . . . . . . . . . . . . . . . . . . . . . . . . . . . 74

6.1 .3 Scaffold Attachment Regions . . . . . . . . . . . . . . . . . . . . . . . . . . 74

6.2 Targeted Recombination Systems in Plants . . . . . . . . . . . . . . . . . . . . 74

7 Intellectual Property . . . . . . . . . . . . . . . . . . . . . . . . . . . . . . 75

References . . . . . . . . . . . . . . . . . . . . . . . 76

\footnotetext{
${ }^{1}$ Department of Horticulture and Crop Science, Plant Molecular Biology and Biotechnology Program, Ohio Agricultural Research and Development Center. The Ohio State University. Wooster. OH 44691. USA

2Department of Biological Sciences. Kent State University, Stark Campus. Canton. ()H 44720. ISA
} 


\section{Introduction}

Since the production of the first genetically engineered plants in the middle 1980s (HoRsCH et al. 1985), there has been an explosion of interest in the production of transgenic plants for both basic and applied work. Large efforts have been placed in the development and refinement of methods for transgenic plant production and also in the isolation and characterization of useful genes for introduction into plants. Through gene transfer, plants have already been produced that contain genes for disease and insect resistance, and modified fruit and grain quality. Many of the products of plant biotechnology would not exist today without particle bombardment gene transfer methods. Using Biolistics, transformation of many plants and tissues that had been recalcitrant to manipulation, has become much more routine. Particle bombardment or Biolistics has been used to transform a large number of different plant species (reviewed by Christou 1994), as well as some animals, fungi, and bacteria.

\section{History}

A new method using high-velocity microprojectiles to deliver exogenous genetic material into plant tissue was developed and first described by John Sanford in collaboration with Ted Klein, Ed Wolf, and Nelson Allen (SANFOrd et al. 1987). In that first study, penetration of particles was easily visualized using onion tissue, where a monolayer of large epidermal cells was used as the target tissue. By observing cytoplasmic streaming in these cells, this tissue could be easily evaluated for viability following bombardment. Onion epidermal cells, transformed with the chloramphenicol acetyl transferase (CAT) gene (KLEIN et al. 1987), were the first transiently transformed cells produced using this method. CAT activity was detected in the tissue 3 days after delivery of particles using an early gunpowder discharge device.

The first stably transformed plants obtained using biolistics were reported by Christou et al. (1988) and Klein et al. (1988) using soybean and tobacco respectively. Christou et al. $(1988,1989)$ bombarded soybean shoot meristems and recovered chimeric plants which subsequently transmitted the introduced gene to progeny. KLEIN et al. (1988) targeted tobacco leaf tissue which formed callus under kanamycin selection. Plants were eventually recovered from the tobacco callus using standard regeneration protocols. Since these initial reports of successful transformation, a broad range of species has been transformed including bacteria (Smith et al. 1992), fungi (Toffaletti et al. 1993) and even animals (JoHNSTON et al. 1991). In addition, organelles such as chloroplasts (BOYNTON et al. 1988) and mitochondria (JoHnston et al. 1988) have also been transformed using Biolistics. 
This method of particle acceleration, which has been described as the particle gun, the gene gun, the bioblaster, and the microprojectile bombardment method was initially christened the "biolistic" method by its inventor (SANFORD 1988). Biolistics, a combination of "biological" and "ballistics". describes a technique which utilizes instrumentation to accelerate DNA coated microprojectiles into cells, past the cell wall and cell membrane. The microprojectile is small enough $(0.5-$ $5 \mu \mathrm{m})$ to enter the plant cell without too much damage, yet large enough to have the mass to penetrate the cell wall and carry an appropriate amount of DNA on its surface into the interior of the plant cell.

Because this is a direct gene transfer method, which does not rely on a biological vector, Biolistics has been used successfully to transform cells that were once impossible to transform by other means. With this technique, the microprojectile is shot through the physical barriers of the cell, and as such. there are no biological limitations to DNA delivery. Transformation via the Biolistics method is simple and safe and DNA delivery appears to be genotype and tissue independent.

The utility of the Biolistic method is broad and the technology can be used for basic studies on transformation (JOHNSTON et al. 1988), modifications of gene expression (NAPOL et al. 1990), understanding essential components of genes (Montgomery et al. 1993) and the production of transgenic plants of economic value (Finer and MCMULlen 1990; Gordon-Kamm et al. 1990; somers et al. 1992: Christou et al. 1991; Bower and Birch 1992; Weeks et al. 1993).

\section{Particle Gun Design}

There are a number of different particle gun designs that are in use in various laboratories. The basis of all of these designs is to coat DNA onto small dense particles and accelerate the particles towards a target tissue. The particles usually consist of either gold or tungsten. Gold particles are chemically inert, produce no cytotoxic effects and are more uniform in size than tungsten particles. However, the cost of gold particles may limit their accessibility and the more affordable tungsten particles are sufficient for most studies. Tungsten particles are somewhat phytotoxic (Russell et al. 1992a) and tend to be more variable in size than gold particles. Ideally the particles used for bombardment should have good initial affinity for the DNA, yet freely release it once in the cytoplasm or nucleus of the target cell.

To prepare DNA-coated microprojectiles, washed gold or tungsten particles are mixed with plasmid DNA. The DNA is bound on the particles using either ethanol or $\mathrm{CaCl}_{2}$ precipitation methods. Spermidine may be added to the mixture, possibly protecting the DNA from degradation and/or altering its conformation. After precipitation, the particles may be washed, resuspended and either dried or stored on ice as an aqueous suspension until use. 
Many of the particle guns utilize a macrocarrier, which supports or carries the particles and is accelerated along with the particles towards the target. The macrocarrier is usually retained by a stopping plate or screen before it collides with the target, whereas the particles continue along their course. In most cases, the particles are accelerated under partial vacuum in a vacuum chamber to reduce air drag. Particle penetration is controlled by modifying the intensity of the explosive burst, by changing the distance that the particles must travel to reach the target tissue or by using different sized particles. Most laboratories use the commercially available devices which can be purchased from BioRad Laboratories (Hercules, CA, USA). Depending on accessibility, financial limitations and specific use, it may be appropriate to consider other devices.

\subsection{The Original Particle Gun}

The original gene gun described in the literature used DNA-coated tungsten particles in an aqueous slurry loaded on the end of a small plastic bullet, which served as the macrocarrier (SANFORD et al. 1987). The plastic macrocarrier was placed into a 0.22 caliber barrel in front of a gun powder cartridge. Once the cartridge was fired, the plastic bullet was propelled towards a solid stopping plate containing a small opening in the center. The microprojectiles continued through the hole towards the target tissue while the macrocarrier was retained. Both the stopping plate and the macrocarrier were discarded afterwards. The initial blast from the gunpowder cartridge necessitated frequent cleaning of the chamber and the target tissue was frequently damaged by the force of the blast. Although large amounts of variation in results were common with this device, this first unit was used successfully by a number of different laboratories.

\subsection{Helium-Modified Bombardment Device}

The first important modification of the original device included the substitution of a helium blast for the gunpowder discharge (SANFOrD et al. 1991). This device, licensed by duPont and marketed by BioRad (Hercules, CA) as the "PDS-1000/He", uses high-pressure helium as the source of particle propulsion. In the PDS-1000/He device, helium pressure continually builds in a reservoir and is released using "rupture discs" which are manufactured to rupture at predetermined pressures. The release of helium produces a shockwave which travels to a second disc or macrocarrier that holds the DNA-coated particles. The macrocarrier carries the DNA coated particles a short distance into a stopping screen which retains the macrocarrier. The microprojectiles continue traveling, ultimately penetrating the target tissue which is held in a partial vacuum. The force of the original shockwave and consequent velocity of the particles can be controlled by using various rupture discs that are made to rupture at different pressures. The PDS-1000/He is the most 
commonly used device and has shown good control of particle acceleration using the various rupture discs.

\subsection{Accel Particle Gun}

The Accel gene gun uses a high voltage electrical discharge to vaporize a water droplet which produces a controlled shock wave (MCCABE and Christou 1993). The device is constructed so that the initial shock wave is reflected to produce secondary shock waves, which in turn accelerate a mylar sheet coated with particles. The mylar sheet is accelerated towards a retaining screen which stops the carrier and allows the particles to continue onto the target tissue. Particle speed, and the resulting depth of particle penetration, may be accurately modified by adjusting the intensity of the voltage passing through the water droplet. The Accel device may be the most efficient particle bombardment device in current use but it is not commercially available and has not received widespread use.

\subsection{Particle Inflow Gun}

The cost of the above devices (due to manufacturing expenses, patenting constraints and licensing) have placed this technology out of reach for many laboratories. This created a need to develop more affordable, simple, yet safe and effective devices such as the Particle Inflow Gun or PIG (FINER et al. 1992). With this device, a solenoid controlled by a timer relay is used to generate a burst of low-pressure helium. The particles, supported by a screen in a reusable syringe filter unit, are accelerated directly in a stream of helium without the need for a macrocarrier. The target tissue is held in a chamber under a partial vacuum. To minimize the localized impact of the particles and to aid in dispersal, a nylon mesh baffle may be placed over the tissue. Advantages of this design include affordability (no purchase of macrocarriers or rupture membranes), less cleanup and minimal down time between shots.

\subsection{Microtargeting Device}

Another particle bombardment device that does not utilize a macrocarrier is the microtargeting device (SAUTTER et al. 1991). This device, which accelerates small amounts of a DNA/particle mixture in a focused stream of high-pressure nitrogen, was originally developed to allow precise delivery of particles to the shoot meristem. DNA is not precipitated on the gold particles but is used as a DNA/particle mixture. If the shoot meristem could be accurately targeted, outgrowth of the resultant chimeral or transgenic shoot could rapidly give transgenic progeny.

Transient expression studies using GUS with the shoot meristem as the target indicated that the microtargeting apparatus had great potential for apical meristem transformation (SAUTTER et al. 1991). Particle delivery was precisely controlled and 
transient expression was limited to the meristematic area. Unfortunately, recovery of transgenic shoots and progeny was never obtained following microtargeting of the shoot meristem. Transformed plants were obtained but not from direct meristem transformation.

If the problems of controlling particle penetration could be overcome and large amounts of meristems could be prepared and individually bombarded, it is conceivable that this device could be effective. However, this is unlikely as only a few microtargeting devices were built and this approach is receiving little attention at present.

\subsection{Helios Gene Gun}

While the above particle guns targeted tissue held in a vacuum, these apparatuses are not very portable and could not be easily used to transform target tissue that was sensitive to those conditions created by an evacuated chamber. The need for a gene gun which could be hand-held and used without vacuum proved the impetus for an additional gun design.

The Helios Gene Gun (BioRad, Hercules, CA) is a hand-held device which uses low-pressure helium to accelerate DNA coated particles from the interior of a small plastic cartridge towards the target tissue. A spacer at the tip of the gun maintains optimal target distance and minimizes cell damage by venting the helium gas away from the tissue. The Helios Gene Gun can accommodate up to 12 loaded cartridges at once thus allowing for multiple firing of the device before reloading is necessary. The greatest utility of this device seems to be in situ transformation of animal cells and tissues (Sundaram et al. 1996).

\section{Comparison to Agrobacterium-Mediated Transformation}

The main advantage of particle bombardment over Agrobacterium is absence of the biological incompatibilities found when using this biological vector. In the plant kingdom, particle bombardment has shown good utility for transformation of conifers, dicots and monocots. However, particle bombardment may not be the method of choice for all gene transfer work in plants as Biolistics does have some drawbacks relating to cost, ease of use, accessibility and end product utility.

Agrobacterium tumefaciens is a gram-negative, soil-borne pathogenic bacterium that has the unique and natural ability to transfer part of its DNA to the cells of a host plant (CHILTON et al. 1977). Unlike Biolistics, transformation with Agrobacterium tumefaciens relies on a host-parasite interaction in order to be successful. Agrobacterium appears to have a limited host range with a preference for some dicots while other dicots and most monocots and conifers are, in general, more recalcitrant to Agrobacterium-mediated transformation. Although these limitations have been tremendously reduced with our increased knowledge of the 
biological vector (HAnsen et al. 1994; Hiel et al. 1994; Ishida et al. 1996; Stachel et al. 1985), host range limitations are still present and do present a barrier to use of Agrobacterium for many plants. In addition, infection of the target tissue requires wounding of that tissue and elimination of Agrobacterium from inoculated tissues may prove problematic.

The main advantages of Agrobacterium are ease of inoculation and cost. Delivery of Agrobacterium is simple and straightforward, and there are no equipment costs involved. Another advantage of Agrobacterium lies in the characterization of transgenics. Transgenic plants obtained via Agrobacterium generally contained more predictable introduced DNAs (TINLAND and HOHN 1995) while particle bombardment, as well as other direct DNA uptake methods give rise to more random and uncontrolled DNA integration events (HADI et al. 1996).

\section{Factors Affecting Particle Bombardment-Mediated Transformation}

Particle bombardment is a physical process of DNA introduction. After the DNAcoated particles are introduced, there are numerous factors that influence gene expression and the subsequent recovery of transgenic plants. These factors are logically related to the ability of the target tissue to process the introduced DNA, resulting in the expression and eventual integration of the foreign DNA. For successful transformation via particle bombardment, the plasmid DNA should be carefully designed and selected, while special attention also needs to be placed on the nature, state and receptivity of the target tissues.

\subsection{Components of the Introduced Plasmid DNA}

The introduced plasmid DNA(s) typically contains the necessary plasmid backbone (which allows growth and selection in the bacterial host), plant marker genes and the gene(s) of interest.

The "plant marker genes" can be selectable markers (which allow growth of transformed plant cells in the presence of a selective agent) and/or scorable markers (reporter genes). The genes themselves are composed of the promoter. coding region and terminator. Introns, enhancers and attachment regions are defined regions of additional DNA that can be used to enhance, modulate or stabilize gene expression.

\subsubsection{Selectable Marker Genes}

Choosing the proper selectable marker gene is critical for the successful recovery of stably transformed tissues. The selectable marker simply allows the transformed cells to proliferate in the presence of a selective agent while nontransformed cells 
either do not grow or multiply at a much reduced rate. Selectable marker genes are usually either antibiotic or herbicide resistance genes. The resistance genes can act either by modifying the selective agent itself to inactivate it or by producing an insensitive form of the normal target of the selective agent.

The most commonly used selectable marker gene is NPTII which imparts resistance to the antibiotic kanamycin (SEKI et al. 1991; Russell et al. 1992b). The NPTII gene product is neomycin phosphotransferase, which inactivates the antibiotic by phosphorylation. Although kanamycin is used most often with NPTII, analogues such as geneticin (G418) and paramomycin are also used with this gene. For some tissues, use of kanamycin with the NPTII gene is adequate while geneticin or paramomycin may be better for other tissues. The use of specific antibiotics and their analogues must be empirically determined for each target tissue. Other antibiotics that are commonly used with selectable marker genes in plants include hygromycin (Finer and MCMullen 1990), phleomycin (Perez et al. 1989) and gentamycin (HAJDUKIEWICZ et al. 1994).

The most commonly used herbicide resistance marker gene is the bar gene (WEEKs et al. 1993; BECKER et al. 1994) which is typically used with species of the Gramineae. The bar gene encodes phosphinothricin acetyl transferase, which inactivates phosphinothricin herbicides by acetylation. The bar gene can be used with bialaphos or glufosinate; again, selection of the proper herbicide must be empirically determined as with antibiotics. Other commonly used herbicide resistance genes impart resistance to glyphosate (ZhOU et al. 1995), sulfonyl ureas (SongsTADT et al. 1996) and dalapon (BUCHANAN-WOLLASTON et al. 1992).

\subsubsection{Reporter Genes}

The most widely used reporter gene for plant transformation work is currently $\beta$ glucuronidase (GUS) (JEFFERSON 1987). For transient expression studies, plant tissue is typically evaluated for GUS expression 2-3 days after bombardment with the GUS gene by immersing the tissue in a solution containing 5-bromo-4-chloro-3indolyl- $\beta$-D-glucuronic acid (x-gluc) for periods of 16-24h. Localized enzyme activity in the intact tissue can be visualized as blue spots or areas within the bombarded tissue. For clearer visualization of GUS-positive regions where chlorophyll interference is a problem, tissues can be transferred to $70 \%-100 \%$ ethanol for removal of chlorophyll after the blue coloration appears. Although GUS gene expression does not require specialized equipment for evaluation, a major disadvantage of using GUS is that histochemical staining results in tissue death. GUS activity in plant tissues can be quantified using a fluorometric assay with 4-methylumbelliferyl $\beta$-D-glucuronide (MUG) as the substrate (JEFFERSON 1987). Fluorometric analysis involves extraction of the GUS enzyme from the tissue and results in quantification of GUS expression. The real advantage of using GUS as a reporter gene is the simplicity of the GUS histochemical assay. Further, the blue GUS-expressing regions can easily be visualized without significant background in most bombarded plant tissues. 
Although the GUS gene has proven to be very useful in monitoring transient expression in a number of species, nondestructive assays for transient expression would provide a significant advantage over a method resulting in tissue death. Plant tissues could be evaluated at various times following bombardment by reporter genes whose expression can be monitored without causing tissue damage. Such a system could greatly reduce the effort and time involved in selection of stable transformants.

The firefly luciferase gene is a nontoxic reporter gene that has been successfully used to monitor gene expression in plants (OW et al. 1987; MILlAR et al. 1992). After the bombarded tissues are treated with luciferin (substrate) solution. luciferase activity is documented using either X-ray film (Ow et al. 1987) or specialized light-sensitive cameras (Michelet and ChuA 1996) to detect a luminescent product. Use of X-ray film can be very inconvenient while low light cameras are somewhat costly and must be used in a dark room. Luciferase activity can also be assayed using extracts of plant tissue that are incubated with the luciferin substrate (GoDON et al. 1993). Unfortunately, detection techniques for luciferase severely limit the flexibility of using this reporter gene.

Genes that encode transcription factors that regulate anthocyanin biosynthesis have also been used as reporter genes. For example, introduction of a chimeric R-gene under a constitutive promoter resulted in red anthocyanin pigmentation in maize tissues that could be easily visualized (Ludwig et al. 1990). The R-gene has not received widespread use because high expression levels may impact plant regeneration and expression is strongly influenced by the genetic background of the target tissue.

Perhaps the most useful reporter gene in current use in plants is the green fluorescent protein (GFP) of the jellyfish (Aequorea victoria). The 238 amino acid native jellyfish GFP has three amino acids (Ser-65-Tyr-66 Gly-67) that cyclize to form a chromophore. The native protein has two excitation maxima by UV $(396 \mathrm{~nm})$ and blue $(475 \mathrm{~nm})$ light with respective emission maxima of 508 and $503 \mathrm{~nm}$ (CubitT et al. 1995). Several modified versions of GFP have been synthesized with the aim of improving its performance as a plant reporter gene. One of the more effective of these versions has an introduced mutation so that the chromophore has threonine substituted for serine at position 65. This engineered "S65T" (which is "red-shifted") GFP has a single excitation peak when illuminated by blue light, and exhibits an elevated fluorescent signal, making detection much easier (CHIU et al. 1996). Wild-type GFP has been modified to alter codon usage, solubility, and/or stability of the protein in plants. These modifications, when combined with alterations in the chromophore, have yielded a very useful and sensitive reporter gene system (PANG et al. 1996; Chiu et al. 1996; HAsllor and Amos 1995; DAvis and Vierstra 1996). Expression of GFP following particle bombardment has been reported in several species including Arabidopsis (CHIU et al. 1996; DAvis and Vierstr^ 1996), onion (CHiu et al. 1996) and both corn and wheat (PANG i et al. 1996). Depending on the target tissue, some red and yellow background fluorescence may be present which could potentially complicate GFP detection. This potential disadvantage may be overcome by use of an appropriately engineered GFP and/or suitable excitation and emission filters that reduce background fluo- 
rescence. While GFP has many potential benefits, it is a relatively new marker gene for plant transformation and the long-term effects of GFP expression on plant growth and development remain unclear.

\subsubsection{Introns}

The presence of introns between the promoter and coding region of a gene can significantly affect gene expression. This phenomenon was first described by CALLIS et al. (1987) and has subsequently been confirmed in several studies (Fromm et al. 1990; VAsil et al. 1991, 1992; Nenra et al. 1994). Monocotyledonous species, in particular the Graminae, show significant enhancement of gene expression when using introns. Introns may act by stabilizing mRNAs, thus leading to greater amounts of translation products (LUEHRSEN and WALBOT 1991, 1994). Introduction of different introns between the cauliflower mosaic virus $35 \mathrm{~S}$ promoter and GUS gene caused significant enhancement of transient gene expression in maize, although the degree of expression varied depending on the intron (VAIN et al. 1996). The same study also revealed that transient expression in bluegrass was unaffected by several introns that stimulated expression in maize, thus indicating that the strength of intron-containing gene constructs vary from species to species within the monocots. Of a number of chimeric GUS genes tested, the ubiquitin (ubi I) intron of maize conferred the greatest activity in both maize and bluegrass in comparison with the intron-less 35S-GUS construct (VAIN et al. 1996). Another interesting observation in this study was that a dicot intron (from chs $A$ of petunia) increased the level of GUS expression in both maize and bluegrass.

Although gene expression in many monocots is clearly affected by the presence of introns (VAIN et al. 1996), the effect of introns in genes introduced into dicots is somewhat less clear. In some studies, gene expression in dicots has increased slightly (NORRIS et al. 1993; LEON et al. 1991), whereas in other investigations, expression has not been stimulated by introns (VANCANNEYT et al. 1990; PasZKOWSKI et al. 1992). This suggests that the use of intron-containing constructs to enhance gene expression is more useful for monocots.

\subsubsection{Promoter Analysis}

The use of reporter genes such as GUS or GFP under control of strong promoters (e.g., CaMV 35S) allows for optimization of transformation efficiency of crop plants. Particle bombardment also provides a rapid and convenient means for evaluation of promoter strength, analysis of the function of different regions of promoters, and for examination of tissue specificity of gene expression. The promoter, either in its entirety or with various deletions/mutations, is fused to a reporter gene and introduced into the target tissue. This approach has successfully been used in a number of different species.

Quantitative analysis of a soybean glycinin promoter-GUS fusion in immature seeds and leaves by particle bombardment indicated seed specific GUS expression (IIDA et al. 1995) and subsequent analysis revealed possible regulatory regions 
within the promoter. MONTGOMERY et al. (1993) used promoter-luciferase fusions to identify regions of the tomato E4 promoter that are involved in ethylene responsiveness. The effects of various physiological conditions on gene expression have been determined by introducing suitable promoter-reporter fusions and observing the reporter gene activity as a result of regulatory factors. These include osmotic stress (ONDE et al. 1994; Raghothama et al. 1993), hormones (KaO et al. 1996; Raghothama et al. 1993; Xu et al. 1996), temperature (White et al. 1994) and light (BANSAL et al. 1992; KaO et al. 1996).

\subsubsection{Codon Usage}

The ability to introduce genes into plants from nonplant sources had led to the realization that genes from different organisms can be processed very differently with respect to their expression when compared with native plant genes (DIEHN et al. 1996). Unaltered DNA from nonplant sources may contain DNAs that are recognized by plants as signals for splicing or polyadenylation. In addition, nonplant DNAs may contain codons that are rare in plant genes. Occurrence of rare codons could actually reduce gene expression by becoming limiting during translation. DNA sequences can be modified to generate mRNA with the more abundant plant codons that are efficiently recognized and read by the translational machinery of plants. Modification and resynthesis of genes can be necessary to obtain high levels of expression of a nonplant gene. Modification of the native GFP gene from jellyfish was necessary to avoid missplicing of a cryptic intron in Arabidopsis (Haseloff et al. 1997). Changes for codon usage resulted in a 300 -fold increase in expression levels of a synthetic Bt gene (Perlak et al. 1993).

\subsection{Target Tissue}

A variety of different plant tissues have been used as targets for particle bombardment-mediated transformation. Selection of the appropriate target tissue is dependent on the nature of the research. For rapid gene expression studies, various plasmid constructions can be introduced into different tissues and transient expression can be quickly analyzed to assess promoter activity without the production of stably transformed plants (IIDA et al. 1995). Almost any tissue can be used for transient expression studies as long as the cell wall is penetrable by the DNA-coated particles. The choice of the appropriate target tissue, physiological state of the plant material, and pre- and postbombardment treatments are critical to the successful regeneration of stable transformants.

\subsubsection{Embryogenic Cultures}

Embryogenic cell cultures have been very useful for the production of stably transformed plants. Particle bombardment of embryogenic maize and wheat cultures was used to generate the first transgenic plants of these species (Fromm et al. 
1990; VAIN et al. 1993; VASIL et al. 1992). Embryogenic cultures provide a reliable source of tissue for optimization of bombardment conditions and can be used for year-round production of transgenic plants. An additional advantage of embryogenic cultures is that proliferation of transformed embryogenic tissue under selective conditions results in the production of solidly transformed embryogenic tissue, which subsequently gives rise to nonchimeric plants. However, the maintenance of long-term embryogenic cultures can be labor-intensive and time-consuming as the appropriate "type" of embryogenic callus or suspension cultured material must be selectively subcultured (REDWAY et al. 1990; VAsIL et al. 1991, 1992). An additional complication is that long-term culture can result in abnormalities that may compromise the usefulness of the transgenic plant (RHoDEs et al. 1988). A 6-year-old embryogenic soybean line that was readily transformed gave rise to regenerated plants (from either transformed or nontransformed cultures) that were sterile (HADI et al. 1996). Interestingly, fertile soybean plants from short-term embryogenic cultures can be generated using similar methodologies, but the younger cultures are apparently not as receptive for stable transformation despite exhibiting high levels of transient expression of bombarded genes (Finer, unpublished).

As a result of the problems encountered with plants regenerated from long-term embryogenic cultures, transformation systems that involve rapid regeneration following particle bombardment have been developed (ALTPETER et al. 1996; BECKER et al. 1994; NeHra et al. 1994). In wheat (BECKer et al. 1994) and maize (KozIEL et al. 1993), immature embryos are either bombarded immediately after excision or cultured for a few days prior to bombardment. Although this approach has eliminated some of the problems of long-term cultures, some of the young target tissues are not very responsive to cell culture manipulations and the continual production of high quality immature embryos as initial explant material can be difficult.

\subsubsection{Shoot Apical Meristems}

One target tissue that most transformation scientists would like to be able to effectively target for production of stable transgenics is the shoot apical meristem. Theoretically, introduction of DNA into shoot meristem cells would result in the production of chimeric plants, where the transformed cells would directly give rise to germ-line tissue and the introduced DNA would be passed on to the progeny. This approach could potentially avoid or reduce tissue culture manipulations but there are many problems with shoot meristem bombardment. First, the target tissue within the shoot meristem can be a few cell layers deep and there are few laboratories that are able to accurately gauge and control the depth of particle penetration (McCABE et al. 1988). With most particle guns, the particles penetrate only one or two cell layers (TAYLOR and VASIL 1991). Second, with particle bombardment, only a small proportion of the cells that receive the introduced genes and express transiently, yield stable events; meaning that a large number of meristems must be prepared. Lastly, the meristem itself is small and delicate and therefore somewhat tedious to prepare in large numbers. In spite of these apparent difficulties, particle bombardment of shoot meristematic cells has been used for the production of 
transgenic plants. It has not yet been possible to bombard and directly generate chimeric shoots that transmit the introduced gene to progeny (SAUTTER et al. 1991), but bombardment of shoot meristematic tissues followed by tissue culture multiplication has resulted in production of transgenics that transmit the introduced DNA to progeny (McCABE et al. 1988).

In a direct comparison of bombardment of shoot tips and embryogenic cultures, SAto et al. (1993) bombarded shoot apices and embryogenic cultures of soybean. Although bombarded shoot tips exhibited limited GUS-expressing regions, GUS sectors were not observed in mature plants and the introduced DNA was not transmitted to progeny. In contrast, bombardment of embryogenic soybean suspensions in the same study yielded numerous GUS-positive clones that were regenerated into nonchimeric plants. Unfortunately, since the bombarded cultures were older, established lines, the plants regenerated from these cultures were sterile. Selection of clones from bombarded shoot apices can be time-consuming and labor intensive, but has resulted in the successful recovery of fertile transgenic plants (Russell et al. 1993; Lowe et al. 1995). In addition, bombardment of meristematic tissue from shoot apices does not require the establishment of long-term callus/embryogenic cultures for bombardment of tissue and the possibility of culture-induced abnormalities is minimized.

In a variation of direct bombardment of the shoot meristem, BIDNEY et al. (1992) bombarded shoot apices of sunflower with particles alone (no DNA) and then inoculated the tissue with Agrobacterium. In this case, particle bombardment was used as a method to wound the target tissue for transformation via Agrobacterium rather than for direct DNA introduction itself. Although the resultant plants were chimeric for the introduced gene(s), it is important to note that many of the transformation events were germ-line and transgenic progeny were recovered.

\subsubsection{Other Target Tissues}

Particle bombardment can be used to introduce DNA into any target tissue that is penetrable by the DNA-coated particles. For stable transformation studies the target tissue should be regenerable, but for transient expression studies any tissue can be tested for expression of a reporter gene. In addition to embryogenic cultures and shoot tips, other tissues that have been subjected to particle bombardment include leaves (KLEIN et al. 1988), root sections (SEKI et al. 1991), stem sections (Loopstra et al. 1992), pollen (Twell et al. 1989; Clark and Sims 1994), styles (Clark and Sims 1994), cereal aleurone cells (KIM et al. 1992) and tassel primordia (Dupuis and PACE 1993).

\subsection{Tissue Treatment}

In addition to choice of the appropriate target material, transformation efficiency can be affected by pre- and postbombardment treatments. One treatment that greatly influences gene expression is osmotic conditioning (FINER and MCMULLEN 1990, 
1991; RuSSELL et al. 1992a; VAIN et al. 1993). Osmotic conditioning can be both preand postbombardment. Tissues are subjected to either partial drying in a laminar flow hood or cultured in a medium containing an osmotic agent such as mannitol and sorbitol at relatively high concentration $(\sim 0.4 \mathrm{M})$. Osmotic treatment can enhance both transient expression as well as significantly increase stable transformation. The osmotica may act by causing plasmolysis of the target cells that lessens or eliminates extrusion of the protoplasm in cells that are penetrated by particles (VAIN et al. 1993).

Other examples of media additives include the use of silver thiosulfate along with mannitol, which increased GUS expression in bombarded scutellar tissue of wheat, presumably by reducing the negative effects of wound ethylene (PERL et al. 1992). Inclusion of abscisic acid with an osmoticum (myo-inositol) increased transient GUS expression 1 day after bombardment of Picea embryogenic cultures (Clapham et al. 1995).

The proper preculture of explant material is also beneficial for successful transformation (Perl et al. 1992; AltPeter et al. 1996; Weeks et al. 1993). Preculture refers to the culture of explant material for a few days prior to bombardment, rather than using freshly isolated explants. Preculture may condition the cells to make them more receptive to DNA uptake and integration. This area is often ignored although proper optimization of preculture conditions could result in significant improvements in transformation efficiency.

\section{The Fate of the Introduced DNA(s)}

Although particle bombardment has been used for DNA delivery to plant cells for some time, it is still unclear what happens to the majority of DNA that is introduced. Transient expression studies indicate that large numbers of cells can receive the particles resulting in approximately 10,000 GUS-positive cells per bombardment (FINER et al. 1992; VAIN et al. 1993). In cells that transiently express the introduced DNA, particles are most often seen either in or directly adjacent to the nucleus (Yamashita et al. 1991). Although the introduced DNA can express as soon as one hour after bombardment (Ponappa et al., unpublished), very few (if any) of the cells that show transient expression become stable transformation events. The majority of the delivered DNA therefore is either degraded or inactivated. In those cells that stably integrate the introduced DNA, the introduced gene may act as expected or express in a completely unpredictable manner. Studies of transgene expression patterns, taken together with the molecular analysis of the introduced DNA(s) do provide some information on the fate of DNA in bombarded plant cells.

\subsection{Recombination}

Molecular analysis of plant tissues transformed using particle bombardment give both simple and complex patterns that are typical for particle bombardment and 
other direct DNA uptake systems. Plasmid DNA which is introduced into plant cells via particle bombardment undergoes recombination with other plasmid molecules as well as with the host chromosomal DNA. An understanding of the results of the recombination process may help to possibly control this process in the future.

Recombination occurs whenever new gene arrangements are formed through exchange, elimination or insertion of DNA. The recombinational insertion of plasmid DNA into sites on the target plant chromosomal DNA is an integration or insertion event. Plasmid DNA can either insert cleanly into plant chromosomal DNA as a single entity or large linkages of plasmids can form and subsequently integrate (the full range of intermediate combinations is possible). Integration of a large chain of plasmids can result in a single insertion event with a high copy number of introduced plasmid DNA. With transformed plant tissue obtained via particle bombardment, a single integration event rarely results in the introduction of a single plasmid.

When large numbers of plasmids integrate into the same site, the plasmids may recombine with each other prior to integration into genomic DNA. If a mixture of two different plasmids is used, recombination can occur between like or unlike plasmids. Recombination and integration of unlike plasmids is called co-transformation. The recombination process itself can occur between the same region (homologous recombination) or different regions (illegitimate recombination) on plasmids. When inter-plasmid homologous recombination occurs, the plasmids seem to form end-to-end arrangements which appear as multiple copy, intense, unit-length bands when analyzed by Southern hybridization analysis (FINER and MCMULLEN 1990). When inter-plasmid illegitimate recombination occurs, Southern analysis results in single intensity fragments which are various lengths ( $\mathrm{H} \wedge \mathrm{DI}$ et al. 1996).

Although the exact fate of DNA introduced via particle bombardment is not clear, it appears that plasmid DNA molecules rearrange or recombine with each other to yield linkages of both whole plasmids and plasmid fragments. The linkages then insert into plant chromosomal DNA. The end result is an uncontrolled arrangement of whole plasmids and plasmid fragments, with one to over 100 copies of the introduced plasmid DNA, all integrated into one to five insertion sites. This end result is undesirable in many cases as the arrangement of plasmid DNA affects the expression of the introduced genes.

\subsubsection{Position Effect}

The expression of the introduced gene(s) is dependent on the nature of the DNA as well as the final physical arrangement of the foreign DNA in the plant genome. The influence that adjacent, native plant DNA has on expression of the introduced DNA is called "position effect" (DEAn et al. 1988; PEACH and Velten 1991). If the forcign DNA integrates in a region of DNA that is active, the introduced gene may be expressed at relatively high levels. If the introduction occurs in a region that is not transcriptionally active, gene expression may be reduced. Although the T-DNA from Agrobacterium is generally inserted into transcriptionally active regions (KonCz et al. 1989; INGELBRECHT et al. 1991), DNA that is introduced via particle bombardment 
shows no known preference for insertion sites. Position effects have been suggested as one explanation for variation in gene expression in different transformed clones. Methylation of introduced DNA has been shown to occur in cases where the introduced gene shows minimal activity (Matzke et al. 1989; Prols and MeYer 1992), but the precise association of methylation with position effects is not clear.

\subsubsection{Co-suppression}

A reduction in expression of a gene resulting from the introduction of multiple copies of the gene is called "co-suppression" (NAPOLI et al. 1990). Co-suppression is useful in some situations when a reduction in expression of a native gene is desirable. Unfortunately, co-suppression is also observed as an undesirable product of particle bombardment-mediated transformation when multiple copies of the same gene are introduced. Transgenic plants that give inconsistent expression of the introduced gene(s) often contain multiple copies of the introduced gene (FINER and MCMULLEN 1991). Single-copy introductions are desirable and generally provide more consistent gene expression.

\subsubsection{Scaffold Attachment Regions}

To stabilize gene expression in transgenic plant tissue, scaffold attachment regions (SARs; also known as matrix attachment/associated regions, MARs) have shown some utility (AlLEN et al. 1993; BREYNE et al. 1992). SARs are regions of DNA which were isolated based on their ability to bind to the nuclear scaffold. For transformation, the SARs are ligated to the flanking regions of the gene of interest. They apparently act by stabilizing or normalizing gene expression rather than enhancing overall activity (BREYNE et al. 1992). SARs from yeast (ALLEN et al. 1993) and tobacco (BREYNe et al. 1992; Allen et al. 1996) have helped to stabilize gene expression in plants while a human and soybean SAR were nonfunctional (BREYNE et al. 1992). The level of stabilization of gene expression from SARs may be related to the affinity of that SAR towards the nuclear matrix of the target plant. Therefore, different SARs must be evaluated in different plants. Particle bombardmentmediated transformation efficiency could potentially be increased using SARs as SAR activity was found in a Transformation Booster Sequence isolated from petunia (GALLiano et al. 1995). SARs appear to be especially useful in cases of high copy number DNA introductions, which would normally result in highly variable gene expression profiles.

\subsection{Targeted Recombination Systems in Plants}

In order to have better control on the expression of the introduced DNA(s), it would be beneficial to predict or direct the site of integration. This can be accomplished through either "agrolistic" transformation or homologous recombination. For agrolistic transformation (HANSEN and Chilton 1996), plant tissues 
are bombarded with plasmids that contain some of the DNA excision components from the Agrobacterium gene transfer system. Approximately $20 \%$ of agrolistically transformed plant cells contained precisely defined DNA inserts that would be expected for Agrohacterium-mediated transformation. For targeting using homologous recombination, genes could potentially be placed in certain areas of the genome based on sequence homology between the introduced and the genomic DNA. Although targeted or homologous recombination is fairly well-characterized in some organisms (Radding 1982; Smith 1988; Petes et al. 1991), it has not been well-studied in higher plants. Very little is known about native plant recombinases (Reiss et al. 1996; Cerutti et al. 1992) with most recombination studies in plants relying on information and genes that are available from nonplant systems.

Two homologous recombination systems that have been evaluated in plants are the Cre-lox system from bacteriophage P1 (BAyley et al. 1992: Albert et al. 1995) and the FLP/FRT system from yeast (LYZNIK et al. 1993; BAR el al. 1996). In these systems, a target site containing specific DNA sequences must be introduced in the plant chromosomal DNA using transformation. Following activation with a specific recombinase, a second piece of DNA replaces the target DNA through homologous recombination. Although these nonplant recombination systems are not yet in wide use, there is much potential for targeted integration of introduced DNA once these systems are fine-tuned and better characterized.

\section{Intellectual Property}

With the spoils of gene transfer come protection of methodologies, DNAs and plant material used to generate those spoils. Particle bombardment is no different, having been patented in the United States by its inventor (SANFORI) et al. 1990). The patenting of new methodologies is viewed by some as a way for greedy inventors to generate money for themselves. Others view patents as a way to protect inventions and promote commercialization of products, especially as the cost and risks associated with development of these products increase.

The owner of a patent has the legal right to prevent others from making, using, or selling inventions claimed by that patent. In the United States, construction of a particle bombardment device or use of the device to generate a product is covered under a series of patents exclusively licensed by E.I. duPont de Nemours (Wilmington, DE). Therefore construction of a particle bombardment device or use of the device to generate a product should not be done, unless a license is obtained. The lease or purchase of a particle acceleration system from BioRad (Hercules, CA), DuPont's exclusive licensee for the particle bombardment equipment. is usually accompanied by an agreement, defining the conditions under which the device can be operated. To use particle bombardment for transformation of crop plants, duPont should be contacted, while Sanford Scientific (Waterloo, NY) should be contacted for use with turf and ornamentals. 
The intent of this section is not to provide a thorough review of the patent art but to make the reader aware that restrictions exist for using particle bombardment. A thorough review of the international patent art is suggested before practicing this technology.

Acknowledgements. Salaries and research support were provided by state and federal funds appropriated to OSU/OARDC and Kent State University. Mention of trademark or proprietary products does not constitute a guarantee or warranty of the product by OSU/OARDC and KSU and also does not imply approval to the exclusion of other products that may also be suitable. OARDC Journal Article No. 110-97.

\section{References}

Albert H, Dale EC, Lee E, Ow DW (1995) Site-specific integration of DNA into wild-type and mutant lox sites placed in the plant genome. Plant J 7:649-659

Allen GC, Hall G, Michalowski S, Newman W, Spiker S, Weissinger AK, Thompson WF (1996) Highlevel transgene expression in plant cells: effects of a strong scaffold attachment region from tobacco. Plant Cell 8:899-913

Allen GC, Hall GE, Childs LC, Weissinger AK, Spiker S, Thompson WF (1993) Scaffold attachment regions increase reporter gene expression in stably transformed plant cells. Plant Cell 5:603-613

Altpeter F, Vasil V, Srivastava V, Stoger E, Vasil IK (1996) Accelerated production of transgenic wheat (Triticum aestivum L.) plants. Plant Cell Rep 16:12-17

Bansal KC, Viret JF, Haley J, Khan BM, Schantz R, Bogorad L (1992) Transient expression from cab-m1 and $r b c s-m 3$ promoter sequences is different in mesophyll and bundle sheath cells in maize leaves. Proc Natl Acad Sci USA 89:3654-3658

Bar M, Leshem B, Gilboa N, Gidoni D (1996) Visual characterization of recombination at FRT-gusA loci in transgenic tobacco mediated by constitutive expression of the native FLP recombinase. TAG 93:407-413

Bayley CC, Morgan M, Dale EC, Ow DW (1992) Exchange of gene activity in transgenic plants catalyzed by the Cre-lox site-specific recombination system. Plant Mol Biol 18:353-361

Becker D, Brettschneider R, Lorz H (1994) Fertile transgenic wheat from microprojectile bombardment of scutellar tissue. Plant J 5:299-307

Bidney D, Scelonge C, Martich J, Burrus M, Sims L, Huffman G (1992) Microprojectile bombardment of plant tissues increases transformation frequency by Agrobacterium tumefaciens. Plant Mol Biol $18: 301-313$

Bower R, Birch RG (1992) Transgenic sugarcane plants via microprojectile bombardment. Plant J 2:4099-416

Boynton JE, Gillham NW, Harris EH, Hosler JP, Johnson AM, Jones AR, Randolph-Anderson BL, Robertson D, Klein TM, Shark KB, Sanford JC (1988) Chloroplast transformation in Chlamydomonas with high velocity microprojectiles. Science 240:1524-1538

Breyne P, Montagu M van, Depicker A, Gheysen G (1992) Characterization of a plant scaffold attachment region in a DNA fragment that normalizes transgene expression in tobacco. Plant Cell 4:463-471

Buchanan-Wollaston V, Snape A, Cannon F (1992) A plant selectable marker gene based on the detoxification of the herbicide dalapon. Plant Cell Rep 11:627-631

Callis J, Fromm M, Walbot V (1987) Introns increase gene expression in cultured maize cells. Genes Dev 1:1183-1200

Cerutti H, Osman M, Grandoni P, Jagendorf AT (1992) A homolog of E. coli RecA protein in plastids of higher plants. Proc Natl Acad Sci USA 89:8068-8072

Chilton M-D, Drummond MJ, Merlo DJ, Sciaky D, Montoya AL, Gordon MP, Nester EW (1977) Stable incorporation of plasmid DNA into higher plant cells: the molecular basis of crown gall tumorigenesis. Cell 11:263-271

Chiu W-L, Niwa Y, Zeng W, Hirano T, Kobayashi H, Sheen J (1996) Engineered GFP as a vital reporter in plants. Curr Biol 6:325-330 
Christou P (1994) Application to plants. In: Yang N-S, Christou P (eds) Particle bombardment technology for gene transfer. Oxford University Press, New York

Christou P. McCabe DE, Swain WF (1988) Stable transformation of soybean callus by DNA coated particles. Plant Physiol 87:671-674

Christou P. Swain WF, Yang N-S, McCabe DE (1989) Inheritance and expression of foreign genes in transgenic soybean plants. Proc Natl Acad Sci USA 86:7500-7504

Christou P. Ford T, Kofron M (1991) Production of transgenic rice (Orlza satira L.) plants from agronomically important indica and japonica varieties via electric discharge particle acceleration of exogenous DNA into immature zygotic embryos. Bio Technology 9:957-96?

Clapham D. Manders G. Yibrah HS, von Arnold S (1995) Enhancement of short- and medium-term expression of transgenes in embryogenic suspensions of Picea ahies (L.) Karst. J Exp Bot 287:655 662

Clark KR, Sims TL (1994) The S-Ribonuclease gene of Petunia hybrida is expressed in nonstylar tissue, including immature anthers. Plant Physiol 106:25 36

Cubitt AB, Heim R, Adams SR, Boyd AE. Gross LA. Tsien RY (1995) Understanding. improving and using green fluorescent proteins. Trends Biochem Sci 20:448 455

Davis SJ, Vierstra RD (1996) Soluble derivatives of green fluorescent protein (GFP) for usc in Arabidopsis thaliana. Weeds World 3:43-48

Dean C, Jones J, Favreau M, Dunsmuir P. Bedbrook J (1988) Influence of flanking sequences on variability in expression levels of an introduced gene in transgenic tobacco plants. Nucleic Acids Res 16:9267-9283

Diehn SH, DeRocher EJ, Green PJ (1996) Problems that can limit the expression of foreign genes in plants: lessons to be learned from Bt. toxin genes. In: Setlow JK (ed) Genetic engineering. principles and methods. Plenum. New York

Dupuis I, Pace GM (1993) Gene transfer to maize male reproductive structure by particle bombardment of tassel primordia. Plant Cell Rep 12:607 611

Finer JJ, McMullen MD (1990) Transformation of Cotton (Gossypium hirsutum) via partick hombardment. Plant Cell Rep 8:586 589

Finer JJ. McMullen MD (1991) Transformation of soybean via particle bombardment of embryogenic suspension culture tissue. In Vitro Cell Dev Biol 27P:175-182

Finer JJ, Vain P, Jones MW, McMullen MD (1992) Development of the particle inflow gun for DNA delivery to plant cells. Plant Cell Rep 11:232-238

Fromm ME, Morrish F. Armstrong C, Williams R, Klein TM (1990) Inheritance and expression of chimeric genes in the progeny of transgenic maize plants. Bio/Technology 8:8.33 8.39

Galliano H, Muller AE, Lucht JM, Meyer P (1995) The transformation booster sequence from Petunia hybrida is a retrotransposon derivative that binds to the nuclear scaffold. Mol Gen (ienet 247:614 622

Godon C, Caboche M, Daniel-Vedele F (1993) Transient plant expression: a simple and reproducible method based on flowing particle gun. Biochimie 75:591 595

Gordon-Kamm WJ, Spencer TM. Mangano ML. Adams TR, Daines RJ, Start W(;. O'Brien JV. Chambers SA. Adams WR, Willetts NG, Rice TB. Mackey (J, Krueger RW, Kausch AP. I emaux PG (1990) Transformation of Maize cells and regeneration of fertile transgenic plants. Plant ( cll 2:603 618

Hadi MZ, McMullen MD, Finer JJ (1996) Transformation of 12 different plasmids into soybean via particle bombardment. Plant Cell Rep 15:500 505

Hajdukiewicz. P, Svab Z. Maliga P (1994) The small, versatile pPZP family of Agrohucterium binary vectors for plant transformation. Plant Mol Biol 25:989-994

Hansen G, Chilton MD (1996) "Agrolistic" transformation of plant cells: integration of T-strands generated in planta. Proc Natl Acad Sci USA 93:14978 14983

Hansen G, Das A. Chilton MD (1994) Constitutive expression of the virulence genes improves the efficiency of plant transformation by Agrohacterium. Proc Natl Acad Sci USA 91:7603 7607

Haseloff J, Siemering KR, Prasher DC. Hodge S (1997) Removal of a cryptic intron and subcellular localization of green fluorescent protein are required to mark transgenic Arabidopsis plants. Proc Natl Acad Sci USA 94:2122 2127

Haseloff J, Amos B (1995) GFP in plants. Trends Genet 11:328 329

Hiei Y. Ohta S, Komari T, Kumashiro T (1994) Efficient transformation of rice (() liza sativa L.) mediated by Agrohacterium and sequence analysis of the boundaries of the T-DNA. Plant J 6:271 282

Horsch RB. Fry JE. Hoffman NL. Eicholtz. D, Rogers SG, Fraley RT (1985) A simple and general method for transferring genes into plants. Science 227:1229-1231

lida A. Nagasawa A, Oeda K (1995) Positive and negative cis-regulatory elements in the soybean glycinin promoter identified by quantitative transient gene expression. Plant Cell Rep 14:539 544 
Ingelbrecht I, Breyne P, Vancompernolle K, Jacobs A, VanMontagu M, Depicker A (1991) Transcriptional interference in transgenic plants. Gene 109:239-242

Ishida Y, Saito H, Ohta S, Hiei Y, Komari T, Kumashiro T (1996) High efficiency transformation of maize (Zea mays L.) mediated by Agrobacterium tumefaciens. Nat Biotechnol 14:745-750

Jefferson RA (1987) Assaying chimeric genes in plants. Plant Mol Biol Rep 5:387-405

Johnston SA, Anziano PQ, Shark K, Sanford JC, Butow RA (1988) Mitochondrial transformation in yeast by bombardment with microprojectiles. Science 240:1538-1541

Johnston SA, Riedy M, DeVit MJ, Sanford JC, McElligot S, Sanders Williams R (1991) Biolistic transformation of animal tissue. In Vitro Cell Dev Biol 27P:11-14

Kao CY, Cocciolone SM, Vasil IK, McCarty DR (1996) Localization and interaction of the cis-acting elements for abscisic acid, VIVIPAROUS1 and light activation of the $\mathrm{Cl}$ gene of maize. Plant Cell 8:1171-1179

Kim JK, Cao J, Wu R (1992) Regulation and interaction of multiple protein factors with the proximal promoter regions of a rice high pI $\alpha$-amylase gene. Mol Gen Genet 232:383-393

Klein TM, Wolf ED, Wu R, Sanford JC (1987) High velocity microprojectiles for delivering nucleic acids into living cells. Nature 327:70-73

Klein TM, Harper EC, Svab Z, Sanford JC, Fromm ME, Maliga P (1988) Stable genetic transformation of intact Nicotiana cells by the particle bombardment process. Proc Natl Acad Sci USA 85:8502-8505

Koncz C, Martini N, Mayerhofer R, Koncz-Kalman Z, Körber H, Redei GP, Schell J (1989) High frequency T-DNA-mediated gene tagging in plants. Proc Natl Acad Sci USA 86:8467-8471

Koziel MG, Beland GL, Bowman C, Carozzi NB, Crenshaw R, Crossland L, Dawson J, Desai N, Hill M, Kadwell S (1993) Field performance of elite transgenic maize plants expressing an insecticidal protein derived from Bacillus thuringiensis. Bio/Technology 11:194-200

Leon P, Planckaert F, Walbot V (1991) Transient gene expression in protoplasts of Phaseolus vulgaris isolated from a cell suspension culture. Plant Physiol 95:968-972

Loopstra CA, Weissinger AK, Sederoff RR (1992) Transient gene expression in differentiating pine wood using microprojectile bombardment. Can J For Res 22:993-996

Lowe K, Bowen B, Hoerster G, Ross M, Bond D, Pierce D, Gordon-Kamm B (1995) Germline transformation of maize following manipulation of chimeric shoot meristems. Bio/Technology 13:677--682

Ludwig SR, Bowen B, Beach L, Wessler SR (1990) A regulatory gene as a novel visible marker for maize transformation. Science 247:449-450

Luehrsen KR, Walbot V (1991) Intron enhancement of gene expression and the splicing efficiency of introns in maize cells. Mol Gen Genet 225:81-93

Luehrsen KR, Walbot V (1994) Addition of A- and U-rich sequence increases the splicing efficiency of a deleted form of a maize intron. Plant Mol Biol 24:449-463

Lyznik LA, Mitchell JC, Hirayama L, Hodges TK (1993) Activity of yeast FLP recombinase in maize and rice protoplasts. Nucleic Acids Res 21:969-975

Matzke MA, Primig M, Trinovski J, Matzke AJM (1989) Reversible methylation and inactivation of marker genes in sequentially transformed tobacco plants. EMBO J 8:643-649

McCabe D, Christou P (1993) Direct DNA transfer using electrical discharge particle acceleration (Accell technology) Plant Cell Tissue Organ Cult 33:227-236

McCabe DE, Swain WF, Martinell BJ, Christou P (1988) Stable transformation of soybean (Glycine max) by particle acceleration. Bio/Technology 6:923-926

Michelet B, Chua N-H (1996) Improvement of Arabidopsis mutant screens based on luciferase imaging in planta. Plant Mol Biol Rep 14:320-329

Millar AJ, Short SR, Hiratsuka K, Chua NH, Kay SA (1992) Firefly luciferase as a reporter of regulated gene expression in higher plants. Plant Mol Biol Rep 10:324-337

Montgomery J, Goldman S, Deikman J, Margossian L, Fischer RL (1993) Identification of an ethyleneresponsive region in the promoter of a fruit ripening gene. Proc Natl Acad Sci USA 90:5939-5943

Napoli C, Lemieux C, Jorgensen R (1990) Introduction of a chimeric chalcone synthase gene into petunia results in reversible co-suppression of homologous genes in transformation. Plant Cell 2:279-289

Nehra NS, Chibbar RN, Leung N, Caswell K, Mallard C, Steinhauer L, Baga M, Kartha KK (1994) Selffertile transgenic wheat plants regenerated from isolated scutellar tissues following microprojectile bombardment with two distinct gene constructs. Plant J 5:285-297

Norris SR, Meyer SE, Callis J (1993) The intron of Arabidopsis thaliana polyubiquitin genes is conserved in location and is a quantitative determinant of chimeric gene expression. Plant Mol Biol 21:895-906

Onde S, Futers TS, Cuming AC (1994) Rapid analysis of an osmotic stress responsive promoter by transient expression. J Exp Bot 45:561-566 
Ow DW, Jacobs JD, Howell SH (1987) Functional regions of the cauliflower mosaic virus 35 S RNA promoter determined by use of the firefly luciferase gene as a reporter of promoter activity. Proc Natl Acad Sci USA 84:4870-4874

Pang SZ, DeBoer DL, Wan Y. Ye G, Layton JG, Neher MK, Armstrong CL. Fry JE. Hinchee MAW, Fromm ME (1996) An improved green fluorescent protein gene as a vital marker in plants. Plant Physiol 112:893-900

Paszkowski J, Peterhans A. Bilang R, Filipowicz W (1992) Expression in transgenic tobacco of the bacterial neomycin phosphotransferase gene modified by intron insertions of various sizes. Plant Mol Biol 19:825-836

Peach C, Velten J (1991) Transgene expression variability (position effect) of CAT and (iUS reporter genes driven by linked divergent T-DNA promoters. Plant Mol Biol 17:49 60)

Perez P. Tiraby G, Kallerhoff J, Perret J (1989) Phleomycin resistance as a dominant selectable marker for plant cell transformation. Plant Mol Biol 13:365-373

Perl A, Kless H, Blumenthal A, Galili G, Galun E (1992) Improvement of plant regeneration and GUS expression in scutellar wheat calli by optimization of culture conditions and DNA-microprojectile delivery procedures. Mol Gen Genet 235:279 284

Perlak FJ, Stone TB, Miskopf YM, Petersen LJ. Parker GB, McPherson SA. Wyman J. Love S. Reed G. Biever D, Fischoff DA (1993) Genetically improved potatoes: protection from damage by Colorado potato beetles. Plant Mol Biol 22:313-321

Petes TD, Malone RE, Symington LS (1991) Recombination in yeast. In: Broach JR. Pringle JR. Jones EW (ed) The molecular and cellular biology of yeast saccharomyces: genome dynamics, protein synthesis and energetics. Cold Spring Harbor Laboratory, Cold Spring Harbor, pp. 407521

Prols F, Meyer P (1992) The methylation patterns of chromosomal integration regions influence gene activity of transferred DNA in Petunia hybrida. Plant J 2:465-475

Radding CM (1982) Homologous pairing and strand exchange in genetic recombination. Annu Rev Genet 16:405-437

Raghothama KG, Liu D. Nelson DE, Hasegawa PM, Bressan RA (1993) Analysis of an osmotically regulated pathogenesis-related osmotin gene promoter. Plant Mol Biol 23:1117 1128

Redway FA, Vasil V, Vasil IK (1990) Characterization of wheat (Triticum aestirum L.) embryogenic cell suspension cultures. Plant Cell Rep 8:714 717

Reiss B. Klemm M, Kosak H, Schell J (1996) RecA protein stimulates homologous recombination in plants. Proc Natl Acad Sci USA 93:3094-3098

Rhodes CA Lowe KS Ruby KL (1988) Plant regeneration from protoplasts isolated from embryogenic maize cell cultures. Biotechnology 6:56-60

Russell JA, Roy MK, Sanford JC (1992a) Physical trauma and tungsten toxicity reduce the efficiency of biolistic transformation. Plant Physiol 98:1050-1056

Russell JA, Roy MK, Sanford JC (1992b) Major improvements in biolistic transformation of suspensioncultured tobacco cells. In Vitro Cell Dev Biol 28P:97-105

Russell DR, Wallace KM. Bathe JH, Martinell BJ, McCabe DE (1993) Stable transformation of Phaseolus vulgaris via electric discharge mediated particle acceleration. Plant Cell Rep 12:165 169

Sanford JC (1988) The biolistic process. Trends Biotechnol 6:299-302

Sanford JC, Klein TM, Wolf ED, Allen N (1987) Delivery of substances into cells and tissues using a particle bombardment process. J Part Sci Tech 5:27 -37

Sanford JC, Wolf ED, Allen NK (1990) Method for transporting substances into living cells and tissues and apparatus therefor. US Patent \#4945050

Sanford JC, Devit MJ, Russell JA. Smith FD. Harpening PR, Roy MK. Johnston SA (1991) An improved helium driven biolistic device. Technique 3:3-16

Sato S, Newell C, Kolacz K. Tredo L, Finer JJ. Hinchee M (1993) Stable transformation via particle bombardment in two different soybean regeneration systems. Plant Cell Rep 12:408 413

Sautter C, Waldner H. Neuhaus-Url G. Galli A. Niehaus G, Potrykus I (1991) Micro-targeting: high efficiency gene transfer using a novel approach for the acceleration of micro-particles. Bio Technology 9:1080-1085

Seki M, Shigemoto N, Komeda Y, Imamura J, Yamada Y, Morikawa H (199) Transgenic Arahidopsis thaliana plants obtained by particle-bombardment-mediated transformation. Appl Microbiol Biotechnol 36:228-230

Smith FD, Harpending PR, Sanford JC (1992) Biolistic transformation of prokaryotes: factors that affect biolistic transformation of very small cells. J Gen Microbiol 138:239 248

Smith GR (1988) Homologous recombination in prokaryotes. Microbiol Rev 52:1 28 
Somers DA, Rines HW, Gu W, Kaeppler HF, Bushnell WR (1992) Fertile, transgenic oat plants. Bio/Technology 10:1589-1594

Songstad DD, Armstrong CL, Petersen WL, Hairston B, Hinchee MAW (1996) Production of transgenic maize plants and progeny by bombardment of Hi-II immature embryos. In Vitro Cell Dev Biol Plant 32:179-183

Stachel SE, Messens E, Van Montagu M, Zambryski P (1985) Identification of the signal molecules produced by wounded plant cells which activate the T-DNA transfer process in Agrobacterium tumefaciens. Nature 318:624-629

Sundaram P, Xiao W, Brandsma JL (1996) Particle mediated delivery of recombinant expression vectors to rabbit skin induces high titered polyclonal antisera (and circumvents purification of a protein immunogen) Nucleic Acids Res 24:1375-1377

Taylor MG, Vasil IK (1991) Histology of, and physical factors affecting, transient GUS expression in pearl millet (Pennisetum glaucum (L.) R Br) embryos following microprojectile bombardment. Plant Cell Rep 10:120-125

Tinland B, Hohn B (1995) Recombination between prokaryotic and eukaryotic DNA: integration of Agrobacterium tumefaciens T-DNA into the plant genome. In: Setlow JK (ed) Genetic engineering. Plenum, New York, pp 209-229

Toffaletti DL, Rude TH, Johnston SA, Durack DT, Perfect JR (1993) Gene Transfer in Cryptococcus neoformans by use of biolistic delivery of DNA. J Bacteriol 175:1405-1411

Twell D, Klein TM, Fromm ME, McCormick S (1989) Transient expression of chimeric genes delivered into pollen by microprojectile bombardment. Plant Physiol 91:1270-1274

Vain P, Finer KR, Engler DE, Pratt RC, Finer JJ (1996) Intron-mediated enhancement of gene expression in maize (Zea mays L.) and bluegrass (Poa pratensis L.) Plant Cell Rep 15:489-494

Vain P, McMullen MD, Finer JJ (1993) Osmotic treatment enhances particle bombardment-mediated transient and stable transformation of maize. Plant Cell Rep 12:84-88

Vancanneyt G, Schmidt R, O’Connor-Sanchez A, Willmitzer L, Rocha-Sosa M (1990) Construction of an intron-containing marker gene: splicing of the intron in transgenic plants and its use in monitoring early events in Agrobacterium-mediated plant transformation. Mol Gen Genet 220:245-250

Vasil V, Brown SM, Re D, Fromm ME, Vasil IK (1991) Stably transformed callus lines from microprojectile bombardment of cell suspension cultures of wheat. Bio/Technology 9:743-747

Vasil V, Castillo AM, Fromm ME, Vasil IK (1992) Herbicide resistant fertile transgenic wheat obtained by microprojectile bombardment of regenerable embryogenic callus. Biotechnology 10:667-674

Weeks TJ, Anderson OD, Blechl AE (1993) Rapid production of multiple independent lines of fertile transgenic wheat (Triticum aestivum) Plant Physiol 102:1077-1084

White TC, Simmonds D, Donaldson P, Singh J (1994) Regulation of BN115, a low-temperature-responsive gene from winter Brassica napus. Plant Physiol 106:917-928

Xu R, Goldman S, Coupe S, Deikman J (1996) Ethylene control of E4 transcription during tomato fruit ripening involves two cooperative cis elements. Plant Mol Biol 31:1117-1127

Yamashita T, Iida A, Morikawa H (1991) Evidence that more than $90 \%$ of $\beta$-glucuronidase-expressing cells after particle bombardment directly receive the foreign gene in their nucleus. Plant Physiol 97:829-831

Zhou H, Arrowsmith JW, Fromm ME, Hironaka CM, Taylor ML, Rodriguez D, Pajeau ME, Brown SM, Santino CG, Fry JE (1995) Glyphosphate-tolerant CP4 and GOX genes as a selectable marker in wheat transformation. Plant Cell Rep 15:159-163 